Journal of English Language Teaching and Applied Linguistics

ISSN: 2707-756X

DOI: $10.32996 /$ jeltal

Journal Homepage: www.al-kindipublisher.com/index.php/jeltal

\title{
Factors Influencing English-majored Freshmen's Speaking Performance at Ho Chi Minh City University of Food Industry
}

\author{
Khanh Cong Ly 8 (D) \\ Ho Chi Minh City University of Food Industry, Ho Chi Minh City, Vietnam \\ $\triangle$ Corresponding Author: Khanh Cong Ly, E-mail: khanhlc@hufi.edu.vn
}

\section{ARTICLE INFORMATION}

Received: May 17, 2021

Accepted: June 11, 2021

Volume: 3

Issue: 6

DOI: 10.32996/jeltal.2021.3.6.15

\section{KEYWORDS}

Speaking difficulties, speaking problems, English-majored freshmen, English-majored students, speaking performance

\section{ABSTRACT}

It has been commonly recognized that many Vietnamese students encounter difficulties in communicating and speaking the English language. This study aims to explore the problems influencing university students' performance in learning English speaking skills. The author carried out this research by surveying 178 English-majored freshmen at Ho Chi Minh City University of Food Industry. The findings from the analyzed quantitative data revealed that the respondents' difficulties mainly came from internal factors. The internal factors were categorized into five main aspects: overuse of L1, weak listening and pronunciation, lack of topical knowledge and ideas, shyness and nervousness, and fear of mistakes and criticism. Some other external factors having less impact on the students' speaking performance involved practicing time, the content of the topics, IELTS-oriented speaking tests, and lecturers' support. This study was expected to help students overcome their internal problems and suggest some recommendations to minimize the undesirable effects of negative factors.

\section{Introduction}

Vietnam is one of 10 countries belonging to the Association of Southeast Asian Nations (ASEAN). In ASEAN, the English language plays an important role as a lingua franca among speakers whose L1 is not English (Kirkpatrick, 2020). In many universities in Vietnam, English is the primary foreign language taught for both English-majored and non-English-majored students. According to the EF EPI (English Proficiency Index), which is researched by Education First (EF), Vietnam was ranked $65^{\text {th }}$ among 100 countries and regions in the world (EF, 2021). This EF EPI is constructed on test data from more than two million test takers worldwide who took the EF Standard English Test or one of EF's English placement tests in 2019 to rank countries and regions by English skills. With the $65^{\text {th }}$ rank, Vietnam has been categorized as "Low Proficiency". As shown in Table 1 , Vietnam witnessed a gradually declining trend from 2015 to 2020 regarding national English proficiency.

Table 1: Proficiency Trend of Vietnam from 2011 to 2020

\begin{tabular}{|c|c|c|c|c|c|c|c|c|c|}
\hline $\mathbf{2 0 1 1}$ & $\mathbf{2 0 1 2}$ & $\mathbf{2 0 1 3}$ & $\mathbf{2 0 1 4}$ & $\mathbf{2 0 1 5}$ & $\mathbf{2 0 1 6}$ & $\mathbf{2 0 1 7}$ & $\mathbf{2 0 1 8}$ & $\mathbf{2 0 1 9}$ & $\mathbf{2 0 2 0}$ \\
\hline$\# 39 / 44$ & $\# 31 / 54$ & $\# \mathbf{2 8} / 60$ & $\# 33 / 63$ & $\# 29 / 70$ & $\# 31 / 72$ & $\# 34 / 80$ & $\# 41 / 88$ & $\# 52 / 100$ & $\# 65 / 100$ \\
\hline Very low & Low & Moderate & Low & Moderate & Moderate & Moderate & Moderate & Low & Low \\
\hline
\end{tabular}

Note. Adapted from https://www.ef.com/wwen/epi/regions/asia/vietnam/. Copyright 2021 by EF.

From the author's own experience as an English lecturer of the Faculty of Foreign Languages of Ho Chi Minh City University of Food Industry (HUFI), several students, both in English major and non-English major, usually show their unwillingness or have some difficulties in practicing speaking English. Furthermore, basing on the author's observation of students' performance when speaking with foreign lecturers, they regularly lack confidence, have no ideas to talk or wait for support from the Vietnamese lecturer.

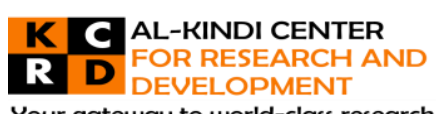

Your gateway to world-class research

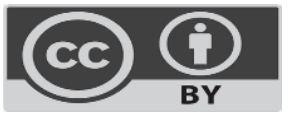

Published by Al-Kindi Center for Research and Development, United Kingdom. Copyright (c) the author(s). This open access article is distributed under a Creative Commons Attribution (CC-BY) 4.0 license 
In order to assist students to enhance their English-speaking skill, their challenges need to be exposed, analyzed, and categorized first. This study discovered freshmen' difficulties, their opinions about various aspects of learning English-speaking skill as well, as their feelings when practicing speaking English at HUFI. From the findings, some suggestions were recommended to help first-year students defeat their own internal problems. In addition, some negative impact from the external issues were mentioned and discussed. The quantitative data of this study was gathered through a survey using online Google Form to obtain students' points of view about different factors affecting their speaking activities.

\section{Literature Review}

It has been generally recognized that many university students in different countries whose L1 is not English deal with challenges in speaking the English language. Woodow and Chapman (2002) remark that "speaking skills are considered a problem for Asian students, because of the lack of exposure to native speakers, and the emphasis on formal exam driven language courses in Asian countries". In the context of Japan, Araki and Raphael (2018) suppose that speaking English can be a big challenge for Japanese university students partly because the Japanese curriculum at high school does not provide students chances for students to present their opinions. In another research conducted in Egypt, El-Sakka (2016) attempts to discover a resolution for the problem of EFL university students at Suez Faculty of Education who cope with high levels of speaking anxiety. In the Turkish context, the foreign language speaking anxiety of 147 Turkish students studying the English preparatory program of a Turkish university was carefully examined by Çağatay (2015) to explore its probable reasons and suggest some measure to it.

Problems related to English speaking skill are an issue in many Asian countries and in Vietnam. There have been some studies investigating this concern in Vietnamese contexts. Many English-majored undergraduates, specifically freshmen, at Can Tho University (CTU) in Vietnam suppose that speaking skills are challenging (Quyen, Nga \& Nguyen, 2018). In another Vietnamese context, Le (2019) implements research to examine the factors that limit students' ability in speaking lessons at Ba Ria - Vung Tau University. The results from the investigation reveal that the significant factors affecting the students' contribution in speaking activities are from teachers, students, and the classroom. In the Master's thesis of Ngô (2010), difficulties in learning speaking English encountered by the freshmen at the Faculty of Information Technology of Thai Nguyen University are also studied. Following the discovery of challenges experienced by these first-year students, various solutions are recommended by the above-mentioned authors and different other scholars to help Vietnamese students deal with the difficulties in speaking English.

There are four key problems that students frequently experience in learning to speak in an authentic classroom: being shy and inhibited, thinking for ideas to say, having the low contribution of individuals, and using L1 (Ur, 2012). Brown (2014, p. 151) states that one of the elements of foreign language anxiety is the "fear of negative social evaluation, arising from a learner's need to make a positive social impression on others". Therefore, English language students are often not confident enough to say their ideas in English because they feel anxious about making mistakes, have a fear of being evaluated by their lecturers or classmates, or feel shy of speaking in front of other people (Ur, 2012).

Many language researchers have examined preceding studies on student's difficulties in speaking English, and several aspects influencing students' speaking performance have been explored. However, most of these studies have just listed out the findings based on raw questionnaire data. Not many studies deeply analyze the students' problems and few types of research classifying the problems into internal and external categories. The aim of this study is to report and analyze some findings on one main research question: What are the factors influencing English-majored first-year students' performance of_speaking English at HUFI?

\section{Methodology \\ 3.1 Design of the study}

Quantitative research can be described as "research that explains phenomena according to numerical data which are analysed by means of mathematically-based methods, especially statistics" (Yilmaz, 2013, p. 311). The quantitative survey design of this study researched HUFI freshmen's problems related to speaking English which were measured with collected numbers and analyzed statistics.

\subsection{Participants}

The respondents of this study were 178 Vietnamese freshmen enrolled in the English Linguistics major at HUFI. There are about 500 first-year students of the school year 2020-2021, so the population size of this study is 500 . With the margin of error $6 \%$ and population proportion $50 \%$, the sample size needs to reach at least 175 respondents in order to have a confidence level of $95 \%$. As a result, the number of participants of this study qualified the confidence level of $95 \%$ that the real value is within $\pm 6 \%$ of the survey value. 
Because all of the survey members are first-year students, their age was 18 or 19. A majority of them have been learning English for a range of time between 7 and 10 years. Although they originate from diverse backgrounds, they are all Vietnamese learners of English. Participants were asked to share private details of their learning experiences. In order to protect their privacy and keep the confidentiality, participants' names and classes were not included in the questionnaire to protect the confidentiality and respect their privacy.

\subsection{Data collection instrument}

In terms of the research question and the aim of this study, quantitative data was collected through a survey questionnaire designed by using the online Google Form. The questionnaire contained 25 questions. The first two questions were infographic ones to obtain the students' general information about their genders and their time in studying English. The following 22 questions of the questionnaire were designed to discover different language components and factors that affect the respondents' performance of speaking English. These 22 survey questions were in the format of the Likert scale, with their level of agreement ranged from strongly disagree (numerically coded as 1) to agree strongly (numerically coded as 5). The last item was an open-ended question that provided the survey contributors with an opportunity to raise their other problems in addition to the previous ones mentioned in the prior 22 questions.

\subsection{Data analysis}

The raw responding data from the questionnaire is collected and transferred into a Microsoft Excel file. Following that, its numeric data is coded and analyzed by using the statistical software IBM SPSS (Statistical Product and Services Solutions) version 22 and reported into tables of results. With the support of SPSS, the reliability of the questionnaire scale was analyzed by calculating Cronbach's alpha. According to Table 2 below, which was extracted from SPSS, Cronbach's Alpha value was 0.852 . If the Alpha value is between 0.84 and 0.90 , it can be described as reliable. Therefore, the reliability of the questionnaire items is acceptable. The descriptive and inferential results are then discussed and interpreted by reaffirming the overall findings. After that, the limitations were indicated and further extended research in the future was recommended (Creswell \& Guetterman, 2019).

Table 2: Reliability statistics

\begin{tabular}{|c|c|}
\hline Cronbach's Alpha & N of Item \\
\hline .852 & 22 \\
\hline
\end{tabular}

\section{Results and Discussion}

\subsection{External factors influencing students' speaking performance}

Nearly 95\% of the HUFI English-majored freshmen believed that speaking skills play a very important role in their future jobs. More than three-fourths of respondents also said that they liked the Speaking subject in class. Several reasons supported their enjoyment of learning to speak English. First of all, about two-thirds of the survey participants shared that they were provided opportunities to practice speaking inside the classroom. Furthermore, just over $60 \%$ of them agreed that the time budget for practising English speaking in class was adequate.

When it comes to nearly two-thirds of the surveyed students thought that the content of the speaking topics in the Speaking textbooks. In this school year, the two textbooks Progressive Skills Level 1 and Progressive Skills Level 2 are used for the subject of Speaking 1 in the first semester, and the next two levels of the same series are being used for the subject of Speaking 2 in the second semester. Although the content of textbooks is about academic English, the speaking mid-term and final speaking tests are designed with the IELTS-oriented format. The English-majored students have to get an IELTS certificate with band 6.5 or above which is equivalent to B2 level according to CEFR (Common European Framework of Reference). Consequently, the purpose of designing speaking tests like IELTS is to help students be familiar with the IELTS speaking format. When asked about what they thought about the IELTS-oriented speaking tests, nearly $75 \%$ of their answers were satisfied with this testing strategy.

In terms of the role of lecturers, about $70 \%$ of the questionnaire participants supposed that the lecturers gave them plenty of time to prepare for a speaking task. The proportion of giving enough time to perform a speaking task was nearly the same as the previous aspect. This result had a correlation to the above-mentioned point that these freshmen were provided many chances to practise speaking in class. Besides, around three-fourths of these first-year students said that the lecturers usually supported correcting their mistakes while they were practising speaking. In general, more than $67 \%$ of the respondents felt that they were satisfied with the Speaking courses of their English major.

Overall, it was assumed that a majority of the surveyed participants had satisfaction with the aforementioned elements. The time allocation and opportunities for practising in class and the content of the textbooks and the IELTS-oriented speaking exams, not 
to mention the support from the lecturers, can be considered external factors affecting HUFI freshmen's speaking performance. Because these elements are mostly related to the syllabus of speaking subjects, they do not come from the respondents' inner ability. Although the students had no interference on the mentioned aspects, these external components did not seriously impact their speaking performance. The data evidently showed that about two-thirds of the responses or more had positive results about the influence of those external features on their speaking performance. It was consequently revealed that their difficulties in speaking English did not mainly initiate from the external factors.

\subsection{Internal factors influencing students' speaking performance}

Listening skills, pronunciation, and fluency are inter-related language aspects that can directly affect speaking performance. When it comes to listening skills, just about $23 \%$ of English-majored freshmen was confident about their listening ability. In contrast, a total of $32 \%$ of these HUFI first-year students were not self-assured about listening to English. Dissimilarly, the trend of pronunciation aspect had an opposite trend in comparison to listening skills. While $16.3 \%$ of respondents said that they were not good at pronunciation, a double percentage (33.2\%) of the survey participants supposed their pronunciation was good. When being asked that whether they could speak fluently or not, there was a balanced proportion between the answers of agreement and disagreement, which was exactly $28.1 \%$.

Coherence and grammar were also mentioned in the questionnaire. Nearly one-third (32.6\%) of the respondents share that they could logically arrange their ideas. Conversely, only one-fifth (20.3\%) of them assumed that their ideas about the speaking topics were not logically arranged during their talks. There was just a slight difference between one side of those who could use a wide range of grammar (26.9\%) and the other side of those who could not apply many grammatical points in their speaking performance (25.3\%).

When it comes to the frequency of using L1 during speaking lessons, more than $61 \%$ of the survey participants confessed that they used a lot of Vietnamese language in their speaking class. This percentage was noticeably high when it was compared to 9\% of the students who did not use much L1 in the speaking time. It seemed that a noticeable number of English-majored freshmen still kept the habit of thinking for ideas and vocabulary in Vietnamese when they were speaking English. One reason which could partly explain for this phenomenon was their lack of topic knowledge about the speaking themes. Nearly one-half of the respondents shared that they did not know the speaking topics. This problem could support the reason why the students usually took time brainstorming for the answers in L1 before translating them into English to speak.

In order to find out the students' difficulties when they speak English, shyness cannot be ignored. When checking if the questionnaire participants had shyness or nervousness in their speaking class, nearly two-thirds of them agreed that they felt shy or nervous. Their inhibition might come from the reason that the students were worried about making mistakes when they spoke. Due to this fear, they tended to be cautious before speaking something. Further than that, these freshmen feared that their audience would criticize them. More than half of the surveyed HUFI students were concerned about criticism or losing face after making speaking errors. All of the factors mentioned above could lead to the appearance of anxiety when students practice speaking English. To avoid the feeling of anxiety, they might incline to be reluctant during English speaking lessons.

Generally speaking, the students' ability to use language skills and aspects is one vital factor influencing their speaking performance. Weak listening skills and pronouncing as well as low fluency in speaking, can lead to poor performance in speaking English. However, when taking a detailed look into the survey results, these difficulties were not the significant issues of these HUFI first-year students. Similarly, although there are problems related to coherence and grammar, they are still not significant problems for these English-majored freshmen. However, regarding the over-use of L1 and lacking topical knowledge, a high proportion of the respondents proved that these factors had a clear negative impact on their speaking process. Most importantly, being shy or nervous can be considered the most crucial factor in making the participants of the survey struggle with speaking lessons. According to the statistics of the questionnaire, fear of making mistakes, criticism or losing face was the main concerns of the surveyed freshmen.

\section{Conclusion}

The purpose of this study is to discover the difficulties of the English-majored first-year students at HUFI when speaking English. From the statistics of the data obtained from an online questionnaire, their problems related to speaking were analyzed and discussed. The results were categorized into two groups named external factors and internal factors in terms of the survey respondents' points of view.

Regarding the first category, external factors refer to outer issues that the students have no control over or interference in a particular learning context. Specifically, these external factors consist of the available chances of practicing speaking in class, the adequate time allocation, the IELTS-oriented speaking tests, and the lecturers' support. Most of these factors relate to the 
curriculum elements of the English Linguistics program. As a result, to minimize the impact of these external features, the management board and all lecturers of the Faculty of Foreign Languages are recommended to have an annual review on the validity and practicality of the current English Language program. Based on the review, necessary adjustments or updates need to be conducted to enhance the program's quality and increase the satisfaction level of its students.

Concerning the second category, internal factors refer to inner problems that the students self-encounter during their learning process. Following this approach, the discovered factors involve students' ability in using language, over-use of L1 in speaking time, lack of topic knowledge about speaking themes, shyness and inhibition. Among these factors, students' ability to use language aspects, which includes listening skills, pronunciation, grammar, and logical arrangement of ideas, has a minor impact on the freshmen's speaking performance. Over-using Vietnamese during the speaking time has a more noticeable influence on these first-year students' speaking problems. Above all, feeling shy and nervous of the survey respondents causes the most significant difficulties in their speaking process.

In order to overcome the challenges in speaking English, students are suggested to learn all English language skills and aspect equally because all of the language components have inter-correlation. This means that it is not a good strategy if the student just focuses on practising speaking skills but forgets to improve pronunciation or listening skills. In addition, students are recommended to limit the use of Vietnamese in their speaking class. Instead, they should try to brainstorm and share their ideas in English. Furthermore, students' inhabitant can be surpassed if they practice speaking with a group of friends. Learning with peers and supporting each other can boost their self-esteem and reduce the fear of speaking English in front of other people. Most importantly, each student needs to have strong motivation and determination to advance their speaking performance.

Besides the findings, some limitations of this study need to be mentioned. The target population of this study is just HUFI English-majored freshmen. It would be better if this study expanded the participants to sophomores, juniors, and seniors as well. Another limitation is that this study mainly concentrates on the English-majored freshmen only. In other words, the results rely on the first-year students' perceptions of their speaking problems. If the viewpoints of the lecturers teaching English speaking were included, the findings could be more wholly covered.

Funding: This research received no external funding.

Conflicts of Interest: The authors declare no conflict of interest.

\section{References}

[1] Araki, N., \& Raphael, J. (2018). Firing the Imagination: Process Drama as Pedagogy for 'Melting' EAP Speaking Anxiety and Increasing Japanese University Students' Confidence in Speaking (pp. 41-58). https://doi.org/10.1007/978-981-10-8264-1_3

[2] Brown, H. D. (2014). Principles of Language Learning and Teaching (6th ed.). White Plains, NY: Pearson Education.

[3] Çağatay, S. (2015). Examining EFL Students' Foreign Language Speaking Anxiety: The Case at a Turkish State University. Procedia - Social and Behavioral Sciences, 199, 648-656. https://doi.org/10.1016/j.sbspro.2015.07.594

[4] EF. (2021, May 11th). EF EPI. Retrieved from EF English Proficiency Index: https://www.ef.com/wwen/epi/

[5] El-Sakka, S. M. F. (2016). Self-Regulated Strategy Instruction for Developing Speaking Proficiency and Reducing Speaking Anxiety of Egyptian University Students. English Language Teaching, 9(12), 22. https://doi.org/10.5539/elt.v9n12p22

[6] Kirkpatrick, A. (2020). English as an ASEAN Lingua Franca. In The Handbook of Asian Englishes (pp. 725-740). Wiley. https://doi.org/10.1002/9781118791882.ch32

[7] Le, M. A., \& Mai, T. (2019). An Investigation into Factors that Hinder the Participation of University Students in English Speaking Lessons. IOSR Journal Of Humanities And Social Science (IOSR-JHSS, 24, 84-94. https://doi.org/10.9790/0837-2404068494

[8] Ngô, P. T. (2010). A study on the difficulties in learning speaking English of the first year students at the Faculty of Information Technology, Thai Nguyen University. http://repository.vnu.edu.vn/handle/VNU_123/40927

[9] Quyen, V.P., Nga, P.T.M., Nguyen, H.T. (2018). Challenges to speaking skills encountered by English-majored students: A story of one Vietnamese university in the Mekong Delta. Can Tho University Journal of Science, 54(5), 38. https://doi.org/10.22144/ctu.jen.2018.022

[10] Ur, P. (2012). A Course in English Language Teaching (2nd ed.). Cambridge: Cambridge University Press.

[11] Woodrow, L., \& Chapman, E. (2002). Second language speaking anxiety of learners of English for academic purposes in Australia.

[12] Yilmaz, K. (2013). Comparison of quantitative and qualitative research traditions: Epistemological, theoretical, and methodological differences. European Journal of Education, 48(2), 311-325. https://doi.org/10.1111/ejed.12014 


\section{Appendix}

Questionnaire: Factors Influencing English-majored Freshmen's Speaking Performance at HUFI

1. What is your gender?

2. How long have you been learning English?

3. You think that speaking skills are necessary to your future job.

4. You like speaking English in class.

5. You usually have chances to practice speaking inside the classroom.

6. You think that the time for practicing speaking in class is adequate.

7. You think that the content of the speaking topics in the textbooks is interesting.

8. You think that the IELTS-oriented speaking mid-term and final tests are relevant to the learning content.

9. The lecturers give you plenty of time to prepare for a speaking task.

10. The lecturers give you plenty of time to perform a speaking task.

11. The lecturers usually correct your mistakes while you are speaking.

12. In general, you have been satisfied with the Speaking courses at your university.

13. Your listening skill is good.

14. Your pronunciation is good.

15. You can easily develop and expand your ideas.

16. You can speak fluently.

17. You can arrange your ideas in a logical way.

18. You can use a wide range of grammar.

19. You use Vietnamese a lot in your speaking class.

20. You do not have much knowledge related to the speaking themes.

21. You are confident when speaking in front of many people.

22. You feel shy or nervous in your Speaking class.

23. You are worried about making mistakes when you speak.

24. You fear criticism or losing face when you speak.

25. What other problems do you encounter in learning English speaking skill? (Please specify) $\square$ Female

$\square$ Under 7 years
$\square$ Strongly

disagree (1)

$\square$ Strongly

disagree (1)

$\square$ Strongly

disagree (1)

$\square$ Strongly

disagree (1)

$\square$ Strongly

disagree (1)

$\square$ Strongly

disagree (1)

$\square$ Strongly

disagree (1)

$\square$ Strongly

disagree (1)

$\square$ Strongly

disagree (1)

$\square$ Strongly

disagree (1)

$\square$ Strongly

disagree (1)

$\square$ Strongly

disagree (1)

$\square$ Strongly

disagree (1)

$\square$ Strongly

disagree (1)

$\square$ Strongly

disagree (1)

$\square$ Strongly

disagree (1)

$\square$ Strongly

disagree (1)

$\square$ Strongly

disagree (1)

$\square$ Strongly

disagree (1)

$\square$ Strongly

disagree (1)

$\square$ Strongly

disagree (1)

$\square$ Strongly

disagree (1)
-10 years

$\square$ Disagree $\quad \square$ Neutral

(2) (3)

$\square$ Disagree

(2)

3)

(3)

$\square$ Disagree

(2)

$\square$ Neutral

$\square$ Disagree

(3)

(2)

$\square$ Disagree

(2)

$\square$ Disagree

(2)

$\square$ Disagree

(2)

$\square$ Disagree

(2)

$\square$ Disagree

(2)

$\square$ Disagree

(2)

$\square$ Disagree

(2)

$\square$ Disagree

(2)

$\square$ Disagree

(2)

$\square$ Disagree

(2)

$\square$ Disagree

(2)

$\square$ Disagree

(2)

$\square$ Disagree

(2)

$\square$ Disagree

(2)

$\square$ Disagree

(2)

$\square$ Disagree

(2)

$\square$ Disagree

(2)

$\square$ Disagree

(2)

$\square$ Neutral

(3)

(3)

$\square$ Neutral

(3)

(3)

$\square$ Neutral

(3)

$\square$ Neutral

(3)

$\square$ Neutral

(3)

(3)

$\square$ Neutral

(3)

$\square$ Neutral

(3) $\square$ Agree $\square$ Strongly

(4)

$\square$ Agree

(4)

(4)

(3) (4)

(3) (4)

(4)

$\square$ Neutral $\square$ Agree

(3) (4)

(4)

(3) (4)

(4)

$\square$ Neutral $\square$ Agree

(3) (4)

$\square$ Agree

(3) (4)

$\square$ Neutral $\square$ Agree

(3) (4)

$\square$ Agree

(4)

$\square$ Agree

(4)

$\square$ Agree

(4)

(3) (4)

(4)

$\square$ Agree

(4)

$\square$ Neutral $\square$ Agree

(3) (4)

$\square$ Agree

(4)

$\square$ Agree

(4)

(4)

$\square$ Agree

$\square$ Agree

(4)

(4) agree (5)

$\square$ Strongly agree (5)

$\square$ Strongly agree (5)

$\square$ Strongly agree (5)

$\square$ Strongly agree (5)

$\square$ Strongly agree (5)

$\square$ Strongly agree (5)

$\square$ Strongly agree (5)

$\square$ Strongly agree (5)

$\square$ Strongly agree (5)

$\square$ Strongly agree (5)

$\square$ Strongly agree (5)

$\square$ Strongly agree (5)

$\square$ Strongly agree (5)

$\square$ Strongly agree (5)

$\square$ Strongly agree (5)

$\square$ Strongly agree (5)

$\square$ Strongly agree (5)

$\square$ Strongly agree (5)

$\square$ Strongly agree (5)

$\square$ Strongly agree (5)

$\square$ Strongly agree (5) 